\title{
Bahasa Negara di Ruang Publik: Peluang dan Tantangan
}

\author{
Emasta Evayanti Simanjuntak \\ Universitas Negeri Medan \\ Jurusan Bahasa dan Sastra Indonesia, Fakultas Bahasa dan Seni, Medan \\ evayantiemasta@gmail.com
}

\begin{abstract}
Abstrak
Undang-Undang Republik Indonesia No. 24 Tahun 2009 mengamanatkan untuk mengembangkan bahasa Indonesia sebagai bahasa nasional, memelihara dan mempertahankan bahasa daerah, serta mengusahakan internasionalisasi bahasa Indonesia. Tugas konstitusi tersebut bukanlah tugas yang mudah mengingat kompleksitas kebahasan yang ada di dalam konteks masyarakat yang global. Tergerusnya posisi bahasa Indonesia di negara sendiri bukanlah tanpa sebab. Sikap bahasa penutur terhadap bahasa Indonesia semakin melemah dan munculnya kebanggaan yang berlebih terhadap penggunaan bahasa asing. Artikel ini memotret realitas kekinian bahasa nasional, bahasa Indonesia, di tengah himpitan bahasa asing di ruang publik. Oleh karena itu, artikel ini menawarkan peluang untuk tetap menjadikan bahasa Indonesia hidup dan bermartabat dalam terpaan dan kencangnya angin globalisasi.
\end{abstract}

Kata Kunci: bahasa negara, ruang publik, sikap bahasa, peluang dan tantangan

\section{PENDAHULUAN}

Tidak terasa, Indonesia akan menginjak usia 75 tahun kemerdekaan. Begitu juga dengan bahasa Indonesia sebagai bahasa negara, ketika Indonesia mengikrarkan Proklamasi Kemerdekaan 1945, sejak saat itu jugalah bahasa Indonesia resmi menjadi bahasa negara. Sementara itu, sebagai bahasa nasional, Bahasa Indonesia akan menginjak usia 92 tahun sejak diikrarkannya Sumpah Pemuda tahun 1928. Bukan usia yang mudah lagi, bukan? Dengan bahasa Indonesia, proklamasi kemerdekaan dikumandangkan. Dengan bahasa
Indonesia, Undang-Undang Dasar 1945 disusun. Dengan bahasa Indonesia, berbagai-bagai suku di Indonesia mencapai keserasian hidup sebagai bangsa yang bersatu dan tidak perlu meninggalkan identitas kesukuan dan kesetiaan pada nilai-nilai sosial budaya serta latar belakang bahasa daerah yang bersangkutan. Lebih dari itu, dengan bahasa Indonesia kita dapat meletakkan kepentingan nasional jauh di atas kepentingan daerah atau golongan.

Pasal 36 UUD 1945 berbunyikan, "Bahasa negara ialah bahasa Indonesia". Hal ini senada dengan Undang-Undang 
Republik Indonesia No. 24 Tahun 2009 yang mengamanatkan untuk mengembangkan bahasa Indonesia sebagai bahasa nasional, memelihara dan mempertahankan bahasa daerah, serta mengusahakan internasionalisasi bahasa Indonesia. Lebih spesifik lagi dijelaskan pada Pasal 25 UU No. 24 Tahun 2009 bahwa bahasa Indonesia sebagai bahasa resmi negara berfungsi sebagai bahasa resmi kenegaraan, pengantar pendidikan, komunikasi tingkat nasional, pengembangan kebudayaan nasional, transaksi dan dokumentasi niaga, serta sarana pengembangan dan pemanfaatan ilmu pengetahuan, teknologi, seni, dan bahasa media massa.

Amanat konstitusional tersebut tentu saja bukanlah tugas yang mudah, mengingat kompleksitas kebahasan yang ada di dalam konteks masyarakat yang global ini. Setiap pengguna bahasa melakukan pergerakan yang amat cepat dan intensif dari satu tempat ke tempat lain. Bahkan, mengingat tuntutan kebutuhan komunikasi yang dihadapi, seseorang harus menggunakan bahasabahasa yang berbeda. Proses alih atau campur kode (bahasa) pun lumrah terjadi, baik peralihan/ percampuran ke dalam (bahasa daerah) dan ke luar (bahasa asing). Pada umumnya, di dalam persaingan kebahasaan terjadi fenomena-fenomena kebahasaan yang diawali dengan kedwibahsaan, diglosia, alih kode/campur kode, interferensi, dan akhirnya permertahanan dan pergeseran bahasa (Adam, 2015: 156).

Di tengah kompleksitas kebahasaan masyarakat global saat ini, bagaimanakah posisi bahasa Indonesia di dalam negara sendiri dan di tengah persaingan global? Peluang dan tantangan apa yang dihadapi bahasa Indonesia di tengah persaingan dunia tanpa batas ini?

\section{SIKAP BAHASA}

Sikap bahasa adalah posisi mental atau perasaan terhadap bahasa sendiri atau bahasa orang lain (Kridalaksana, 2001: 197). Sikap bahasa itu bisa berupa sikap positif dan sikap negatif. Sikap positif yang dimaksud adalah kesetiaan bahasa (language loyalty), kebanggaan bahasa (language pride), dan kesadaran adanya norma bahasa (awareness of the norm). Sebaliknya, kalau ketiga ciri sikap bahasa itu sudah menghilang atau melemah dari diri seseorang atau dari diri sekelompok orang anggota masyarakat tutur, sikat negatif terhadap suatu bahasa telah melanda diri orang atau kelompok orang itu (Chaer dan Agustina, 2010: 152).

Bahasa Indonesia kini sudah semakin luas dipakai oleh berbagai kalangan di tanah air meskipun dapat dipastikan bahwa belum semua lapisan masyarakat Indonesia menggunakannya. 
Penelitian Chaer tahun 1993 (dalam Chaer dan Agustina, 2010: 151-152) menyatakan bahwa keadaan (sikap bahasa Indonesia) sekarang memang sudah jauh berubah. Yang bersikap negatif terhadap bahasa Indonesia sudah jauh berkurang jumlahnya, berkat penjelasan, penerangan, dan kampanye yang dilakukan banyak pihak mengenai kemampuan bahasa Indonesia untuk menjadi bahasa nasional, bahasa negara, bahasa ilmu pengetahuan, bahkan bahasa penghubung antarbangsa, setidaknya di kawasan Asia Tenggara. Namun, apakah keadaan itu semakin membaik sekarang ini?

Penggunaan bahasa negara sangat dipengaruhi oleh deras dan kuatnya tekanan bahasa asing pun bahasa daerah. Setiap kelompok pengguna bahasa Indonesia itu unik sesuai dengan perannya masing-masing. Pada bagian ini akan disajikan hasil pengamatan sekilas pandang tentang penggunaan bahasa Indonesia yang masing-masing memiliki peran yang amat berbeda. Dapat dilihat bagaimana masyarakat menggunakan bahasa Indonesia di beberapa ruang publik.

\section{Dalam Dunia Pendidikan}

Dalam UUD 1945 sudah jelas bahwa bahasa resmi negara dalam dunia pendidikan adalah bahasa Indonesia. Namun, kenyataannya tidaklah demikian yang terjadi di lapangan. Sekarang ini, sekolah berstandar internasional (SBI) menjalar di mana-mana. Orang tua berlomba-lomba menyekolahkan anaknya di sekolah-sekolah tersebut. Orang tua sangat bangga jika anaknya mahir berbahasa asing (baca: Inggris dan Mandarin). Lebih bangga lagi jika dalam keseharian, anak-anaknya menggunakan bahasa asing tersebut. Hampir-hampir, bahasa Indonesia tersisihkan di tengahtengah sekolah yang berlabel internasional.

Sekolah-sekolah yang menerapkan bahasa asing, khususnya bahasa Inggris, sebagai bahasa pengantar di sekolah menjadi nilai jual tinggi di tengah-tengah masyarakat. Sesungguhnya, kondisi ini sudah menyalahi konstitusi yang berlaku di Indonesia. Sungguh aneh, seharusnya yang berstandar internasional itu adalah kualitas pembelajarannya, bukan bahasanya. Namun, yang terjadi malah bahasa penggantar pendidikannya yang menggunakan bahasa internasional. Sementara, kualitas pembelajarannya belum tentu.

Tidak jauh berbeda dengan perguruan tinggi (PT) di Indonesia. kurikulum berstandar internasional menjadi nilai jual saat ini. Kualitas pendidikan internasional yang diharapkan, bukan bahasa internasional yang merajai pendidikan hingga bahasa Indonesia tersisihkan di negara sendiri. Padahal, dunia pendidikan seharusnya menjadi 
garda terdepan untuk menjaga dan mempertahankan posisi bahasa Indonesia di tengah-tengah persaingan global saat ini.

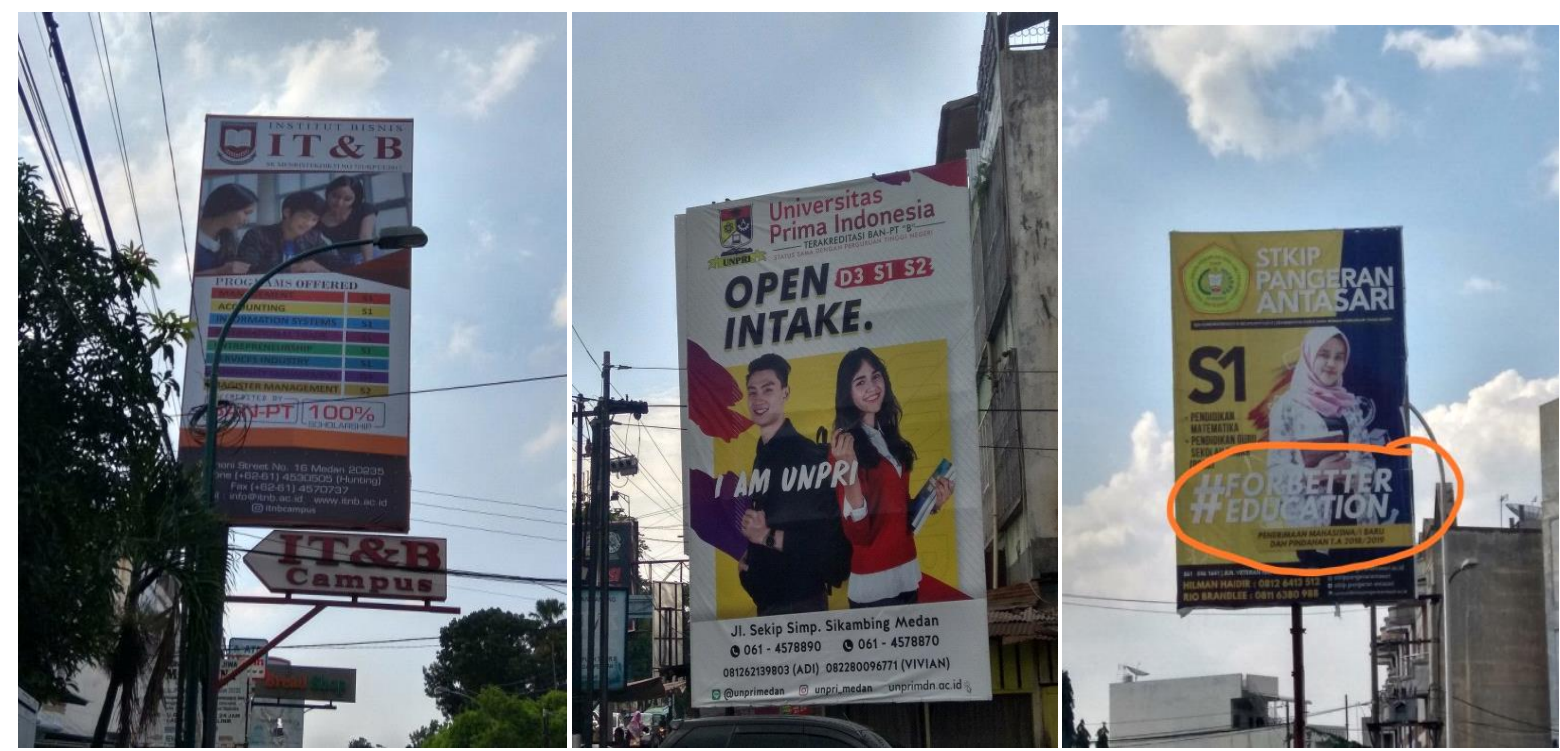

Gambar 1. Penggunaan Bahasa dalam Iklan Pendidikan

\section{Dalam Media Massa}

Media massa, baik cetak maupun elektronik, merupakan ruang yang paling luas dan dahsyat jangkauan serta kekuatannya dalam memengaruhi para pengguna bahasa. Media massa banyak membentuk perilaku berbahasa masyarakat. Penggunaan bahasa di media massa dapat dibedakan dalam dua jenis. Pertama, bahasa yang dipakai oleh para awak media itu, baik wartawan, penyiar, ataupun reporter yang dapat disebut sebagai pewarta. Kedua adalah bahasa yang digunakan oleh pemilik atau sumber berita (Azis, 2013: 6).

Bahasa-bahasa yang digunakan dalam media massa memiliki kekuatan memengaruhi sikap bahasa masyarakat terhadap bahasa negaranya. Pilihan bahasa yang digunakan para pewarta dalam menyampaikan informasi ataupun opininya kepada publik menjadi satu sisi yang diyakini dapat menarik perhatian pemirsa. Pada akhirnya, sesuatu yang dapat ditiru dan menjadi kebiasaan. Masih belum lekang dari ingatan tentang kasus bahasa "vickynisasi” oleh Vicky Prasetyo. Lewat media massa, kasus bahasa Vicky ini mendapat sorotan publik karena tata bahasanya yang acak-acakan. Yang sekarang, aktor sekaligus presenter, Boy William sering diperbincangkan publik remaja karena sikap bahasanya yang paling dominan menggunakan bahasa Inggris dalam setiap membawakan acara. 
Kasus alih atau campur unsur bahasa asing pun dapat dijumpai dalam berbagai judul siaran televisi di Indonesia. Hal ini pun menunjukkan sikap bahasa negatif terhadap bahasa Indonesia, apakah itu disengaja ataupun tidak. Dalam satu hari saja, dapat dilihat beberapa judul siaran yang mencampurkan atau seluruhnya bahasa Inggris dengan konten acara bahasa Indonesia.
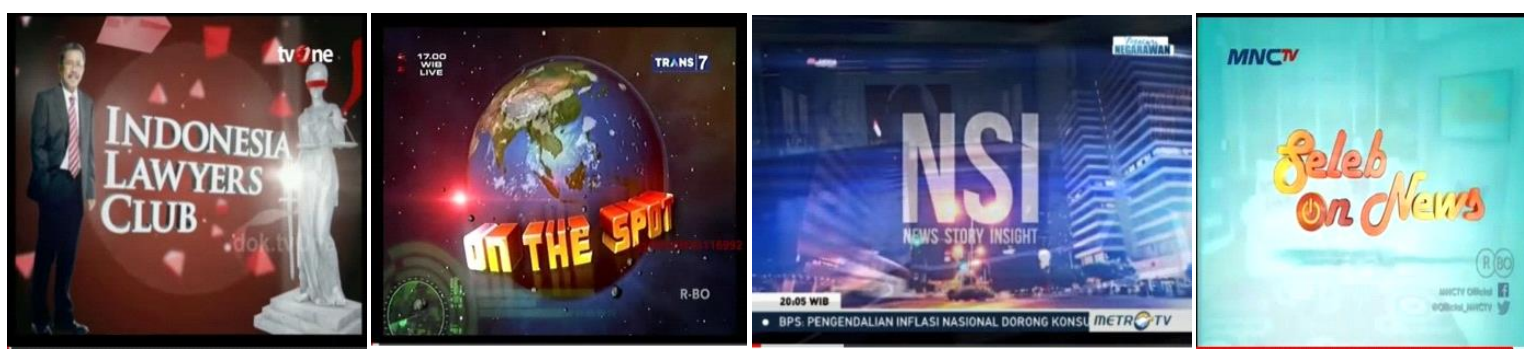

Gambar 2. Judul Acara Siaran di Beberapa Televisi Indonesia

Masyarakat Umum

Masyarakat umum adalah lumbung pemertahanan dan pengembangan bahasa Indonesia. Kelompok masyarakat yang dimaksud di sini adalah masyarakat pengusaha, baik kalangan elite maupun bawah. Para pengusaha pengembang perumahan, misalnya,

banyak menggunakan istilah-istilah dari bahasa asing untuk kompleks perumahan yang mereka bangun. Demikian pula para pengusaha hotel, tempat rekreasi, taman hiburan, rumah makan, atau produk barang-barang konsumsi rumah tangga.
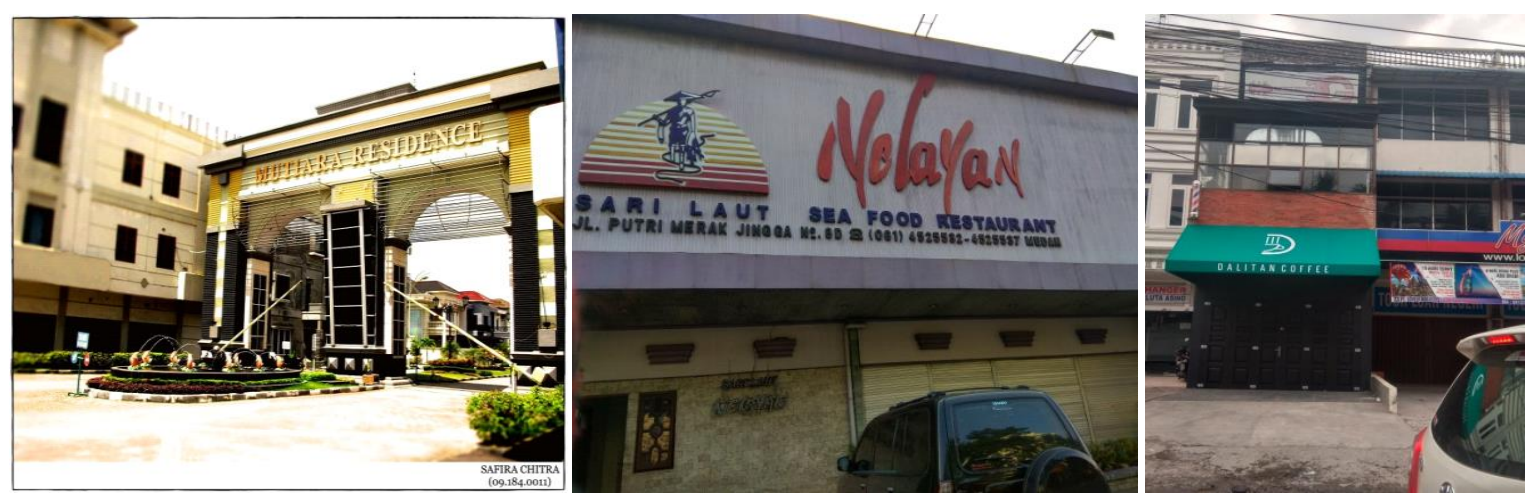

Gambar 3. Penggunaan Bahasa untuk Nama Usaha dan Perumahan

Para pengusaha besar bahkan tidak tanggung-tanggung untuk menggunakan iklan produknya dengan menggunakan bahasa asing seluruhnya. Begitu juga di tempat-tempat perbelanjaan, petunjuk arah atau tempat masih menggunakan bahasa
Inggris, misalnya, left, right, open, close, women's restroom, men's restroom, ATM center, baby area, office area, personal care area, dessert corner, dan customer service. Untuk menyatakan potongan harga, digunakan kata-kata, seperti special 
price, best price, best buy, dan discount. Juga di pintu masuk dan keluar, masih ditemukan ungkapan welcome dan thank you, tanpa diterjemahkan ke dalam bahasa Indonesia. Sungguh, bahasa Indonesia menjadi anak tiri di rumahnya sendiri.
Padahal, pengutamaan bukan berarti melepaskan bahasa asing. Penggunaan bahasa asing tetap dibolehkan, tetapi harus mengutamakan bahasa Indonesia terlebih dahulu.
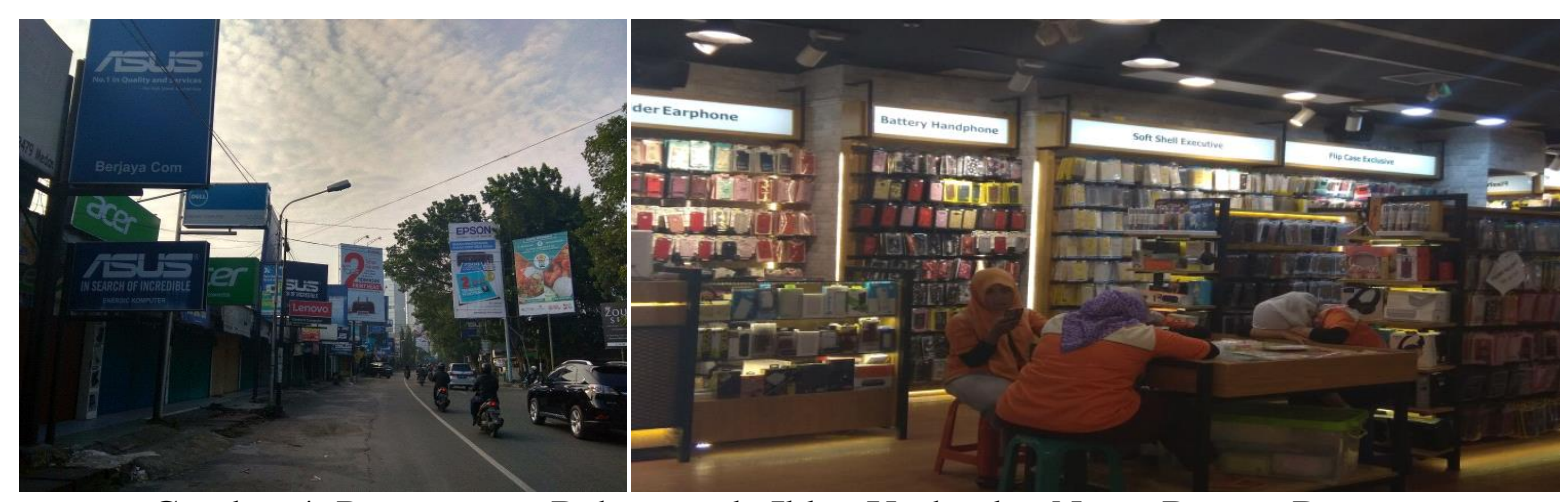

Gambar 4. Penggunaan Bahasa pada Iklan Usaha dan Nama Barang Dagang

\section{Peluang Bahasa Indonesia}

Tantangan yang dihadapai bahasa Indonesia sebagai bahasa negara memang sungguh berat. Interferensi dan integrasi bahasa di tengah masyarakat tutur yang multilingual tidak dapat dihindari. Jika interferensi dan integrasi bahasa (asing dan daerah) dipandang sebagai domain untuk mengembangkan bahasa Indonesia, hal tersebut tidak masalah. Yang menjadi masalah saat ini adalah interferensi bahasa berperan sebagai pengacau atau perusak, bahkan menggantikan posisi bahasa Indonesia itu sendiri, seperti yang diuraikan sebelumnya.

Ruang publik sebagai tempat yang strategis untuk memasyarakatkan bahasa Indonesia seharusnya mendapat perhatian semua kalangan. Sebab, sudah terbukti bahwa politik bahasa yang sifatnya hanya perintah dari atas ke bawah (top down policy) belum berhasil menjamin tumbuhnya kebanggaan memiliki dan menggunakan bahasa Indonesia di kalangan para penuturnya. Sementara itu, diketahui bahwa bahasa Indonesia kini telah menjadi bahasa potensial untuk dipelajari oleh masyarakat internasional dikarenakan kemajuan yang ditunjukkan Indonesia di segala sektor, utamanya bidang ekonomi. Peluang itu sungguh ada. Diketahui bahwa, bahasa Indonesia sudah dipelajari di 45 negara.

\section{SIMPULAN}

Melihat peluang itu, bahasa Indonesia harus difungsikan tidak hanya 
sebagai bahasa pengantar seperti di awal pertumbuhannya, tetapi juga diberikan peran sebagai bahasa ilmu, bahasa bisnis, bahasa sastra, dan cerminan harga diri penutur dan bangsanya. Bahasa Indonesia bukan hanya menjadi tali pengikat antarsuku bangsa untuk bisa saling memahami isi komunikasi di antara mereka. Lebih jauh lagi, bahasa Indonesia harus naik perannya menjadi instrumen yang akan digunakan penuturnya dalam setiap komunikasinya.

\section{DAFTAR PUSTAKA}

Aziz, Aminudin. E., 2013. "Upaya Pemartabatan Bahasa Nasional di Tengah Beratnya Terpaan", artikel dalam Kongres Bahasa X. Jakarta: Badan Pengembangan dan Pembinaan Bahasa Kementerian Pendidikan dan Kebudayaan.

Badan Pengembangan dan Pembinaan Bahasa. 2011. Undang-undang Republik Indonesia Nomor 23 Tahun 2009 tentang Bendera, Bahasa, dan Lambang Negara, serta Lagu Kebangsaan. Jakarta: Kementerian Pendidikan dan Kebudayaan.

Chaer A. dan Agustina L. 2010. Sosiolinguistik Perkenalan Awal. Jakarta: Rineka Cipta.

Kridalaksana, Harimurti. 2001. Kamus Linguistik. Jakarta: PT Gramedia Pustaka Utama.
Sutisno, Adam. 2015. "Perkembangan Bahasa Indonesia pada Era Teknologi Informasi dan Komunikasi”, artikel dalam gramatika.kemendikbud.go.id. 